\title{
Key quality attributes according to the tourist product
}

\author{
Juan José Blázquez ${ }^{1}$, Arturo Molina ${ }^{1 *}$ and Águeda Esteban ${ }^{1}$
}

Received: 20/10/2011 Accepted: 06/02/2012

\footnotetext{
${ }^{1}$ Department of Marketing, Faculty of Social Sciences, University of Castilla-La Mancha Cobertizo San Pedro Mártir s/n, 45071 Toledo, Spain

* Corresponding author; phone: +34 902 204100, fax: +34 902 204130, e-mail: arturo.molina@uclm.es
}

\begin{abstract}
Tourism industry is facing fundamental changes in the profile of tourists and increased competition, due to the emergence of new tourist destinations. One of the main strategies to improve the competitive position is to increase the quality of the destination's resources according to the tourists' expectations. Therefore, the purpose of this study is to identify the destination elements that exercise a greater influence on the tourist's global quality perception, based on the three tourist typologies: sun-sea-sand tourism, rural tourism and cultural tourism. Multiple item indicators from previous studies were employed to measure the quality of destinations. This paper uses Logistic Regression Analysis to establish a model of indicators of global quality of the destination in order to suggest recommendations to manage companies that operate in the different tourist destinations when planning their activities that focus on better quality.
\end{abstract}

(C) 2012 International University College. All rights reserved

Keywords: tourist destination, perceived quality, tourist typologies, logistic regression

Citation: Blázquez, J., A. Molina, Á. Esteban (2012) Key quality attributes according to the tourist product. European Journal of Tourism Research 5(2), pp. 166-170

\section{Introduction}

Nowadays, tourism market is more competitive than in previous decades. The emergence of new tourist destinations and the changes in the role that tourists play, who prefer the development of individualized experiences, have turned the tourism into one of the fastest growing economic sectors in recent years. With the increased competition in tourism, destinations need to find new marketing strategies to achieve a better competitive position and to increase the attractiveness related to other destinations (Dwyer et al., 2004).
Different authors report that destination quality is very important for the competitiveness in tourism (Baloglu et al., 2003), becoming a potential source of competitive advantage. In this sense, Kandampully (2000) states that quality must be the main tourist driving force and that organizations use it to match future competitive challenges. Therefore, improving quality is identified as one of the best competitive strategies to destinations, mainly through its effects on tourist satisfaction and the generation of positive attitudes and behaviours towards destination (Baker and 
Crompton, 2000; Tam, 2000; Kozak, 2001; Alegre and Cladera, 2006).

Tourist destinations are considered extremely complex products (Weaver, Weber and McCleary, 2007), as a result of the sum of tangible and intangible resources. Several authors have analyzed the quality of destination by means of the study of these elements or resources (Pizam and Milman, 1993; Kozak and Rimmington, 2000; Kozak et al., 2004; Alegre and Cladera, 2006; Weaver, Weber and McCleary, 2007), with the aim of finding the ones that show a greater power of attraction. Additionally, a destination may be assessed in a global way (Bigné, Font and Andreu, 2000), since it is considered an entity or unique system and it is perceived by tourists as a global experience (Murphy, Pritchard and Smith, 2000).

However, not all resources are equally important for visitors (Illum and Schaefer, 1995), as the increase in the perceived quality does not always lead to a superior perception of the destination as system. For that reason, it is necessary to identify key resources which have greater influence on the overall perception of the destination (Narayan et al., 2009).

On the other hand, some authors stated that the variables that define the quality differ according to the industry, the market or the destination (Kozak, 2001; McKercher and Wong, 2004). For example, a destination itself can use its resources in order to develop different tourist products (e.g. rural tourism and cultural tourism), and it may not obtain the same results. That is to say that the resources that can be important for the global perception of the destination in the case of rural tourism may not be so for the cultural tourism. To the authors' best knowledge, there is not a previous study which deals with an analysis comparing the differences in key attributes of different tourism products.

Once the relevant literature has been reviewed, the main objective of the study is to discover the key resources that determine the overall quality perception of tourist destinations according to the three most important tourist typologies (sun-sea-sand, rural and cultural). The research on these factors will enable us to answer the following questions: What are the key attributes that influence the global quality perception of the tourist in connection with this type of product? Are there any differences among the resources that generate quality perception if the kind of tourist product offered is taken into account?

\section{Method}

First of all, the population and sampling procedure was established. In order to control cultural or nationality effects on the quality perception (e.g. McKercher and Wong, 2004; Kvist and Klefsjo, 2006), this study was conducted with tourists who had travelled along the previous 12 months. A representative sample was selected taking into account the tourist typologies, specifically the tourist product chosen in the last trip (sun-sea-sand, rural and cultural). The International Tourism Trade Fair (FITUR) in Spain was selected for the collection of information. The selection of the sampling units was made by quota sampling and personal interviews were used with each selected unit. The final sample resulted in 667 tourists (320 sun-sea-sand tourists, 215 cultural tourists and 132 rural tourists).

The survey was developed based on two sections: socio-demographic profile and quality attributes common to the three types of tourist products. To obtain information related to the perceived quality, a measurement scale was developed ad hoc for the study in two stages. Firstly, twenty eight items measuring perceived quality were adapted from a comprehensive review of the destination quality and satisfaction research (e.g. Pizam, Neumann and Reichel, 1978; Kozak and Rimmington, 2000; Fallon and Schofield, 2006; Hui, Wan and $\mathrm{Ho}, 2007)$. The main purpose was to obtain a set of variables common to the three tourist typologies; for that reason, those variables that were not applicable to any type of tourism were removed or modified (e.g. beach cleanliness). In the second stage, a tourism and marketing experts' panel was held, with the objective of filtering and improving the scale. Finally, twenty one items were selected. Even though many researchers have used 
performance-only measurement of quality destination, in tourism it is very important to consider the previous tourists' expectations about the destination. Some authors suggested that a superior alternative may be to measure directly a respondent's perception of the quality of performance against a standard expectation (Carman, 1990; Teas, 1993). Accordingly, our study measured perceived quality through a subjective disconfirmation measurement (Baker and Crompton, 2000; Tam, 2000). All quality questions were measured on a 7-point Likerttype scale, ranging from much worse than expected to much better than expected. The global quality perception was measured by means of a single item with a two-choice answer: "high perceived quality" or "low perceived quality".

The chosen technique was the logistic regression analysis, which will allow us to display a model of indicators of the main characteristics that predict the perceived quality in sun-sea-sand, rural and cultural destinations. In this research, the logistic regression analysis considers the perception of high or low quality of the destination as a dependent variable and all of its characteristics, being 21 in total, as independent variables. In order to evaluate the model parameters, estimation by likelihood procedure was used, as well as the Wald statistic was calculated to assess the significance of the regression coefficients.

\section{Findings and conclusions}

The results try to identify the destination elements that have a greater influence on the tourist's global quality perception, based on the three tourist typologies. This model's regression coefficients present values that allow confirm that the estimated variables are significant $(p<0.01 ; \quad p<0.05)$, except for Availability of Facilities $(\mathrm{p}<0.10)$ in rural tourism (see Table 1). As the value given to each one of the variables obtained increases, the likelihood of the destination being of high quality is also greater. On the other hand, the exponential of a parameter means that a unitary increase of the value given by a tourist to any of the items multiplies - by the value obtained - the odds ratio of indicating an increased quality of the destination.
The goodness of fit test or predictive efficiency of the model is calculated by means of a comparison of the predictions with the data observed in the classification results. To complete this measurement, the statistical significance of the correctness ratio is calculated based on Huberty's Test, and the $Z^{*}$ statistic obtained follows a normal distribution. The classification is conducive to affirming that the model provides a good predictive efficiency, as the global percentage of correctly-classified cases is over $80 \%$ for the three tourist typologies $(88.4 \%$ sun-sea-sand tourism, $80.2 \%$ rural tourism and $87.0 \%$ cultural tourism). Furthermore, in order to statistically check that the global correctness ratio is significant and that it differs from the expected classification only randomly, we turn to Huberty's Test and calculate the $Z^{*}$ statistic, which is distributed as a normal one, obtaining in the three cases valid values for a significance level of $\alpha=0.05$. Therefore, the correctness ratio of this model is significantly higher than the results expected for cases classified at random.

This study has permitted to obtain a set of theoretical and applied conclusions, with regard to the perceived quality in three types of tourist products. The results show that differences exist in the quality perception of the variables analyzed for each type of tourist products. Therefore, the objective posed has been achieved. This research has contributed to identify the real indicators of global quality according to the type of tourist product and it has established a "high quality" configuration. Specifically, the results obtained from the regressions used can be summarized as follows: (1) in the sun-sea-sand destinations the factors that have the greatest effect on the perceived quality are based on the configuration of the destination as a place to get away from one's routine and the stress of daily life, considering the importance of cleanliness, the existence of accessible natural spaces and night life; (2) the destinations focused on rural tourism are also considered as an alternative for tranquillity, with hospitality shown by the residents towards the tourists having a great importance. The existence of an adequate lodging infrastructure and spaces for developing a wide range of activities is also 
Blázquez, J., A. Molina, Á. Esteban / European Journal of Tourism Research 5(2), pp. 166-170

Table 1. Logistic Regression Analysis. Statistics for Variables in the Equations

\begin{tabular}{|c|c|c|c|c|c|c|c|}
\hline $\begin{array}{c}\text { Tourist } \\
\text { typology }\end{array}$ & Variable & $\beta$ & E.E. & Wald & df & Sig. & $\operatorname{Exp}(\beta)$ \\
\hline Sun-Sea-Sand & Cleanliness & 0.787 & 0.203 & 15.093 & 1 & 0.000 & 2.198 \\
\hline \multirow[t]{4}{*}{ Tourism } & Natural Environment & 0.476 & 0.165 & 8.369 & 1 & 0.004 & 1.610 \\
\hline & Night Life & 0.751 & 0.158 & 22.523 & 1 & 0.000 & 2.119 \\
\hline & $\begin{array}{l}\text { Relaxing } \\
\text { Atmosphere }\end{array}$ & 0.929 & 0.170 & 29.839 & 1 & 0.000 & 2.532 \\
\hline & Constant & -12.507 & 1.732 & 52.174 & 1 & 0.000 & 0.000 \\
\hline \multirow[t]{7}{*}{ Rural Tourism } & Cleanliness & 1.207 & 0.390 & 9.587 & 1 & 0.002 & 3.344 \\
\hline & Accommodation & 0.598 & 0.305 & 3.843 & 1 & 0.050 & 1.818 \\
\hline & $\begin{array}{l}\text { Availability of } \\
\text { Facilities }\end{array}$ & 0.527 & 0.315 & 2.810 & 1 & 0.094 & 1.694 \\
\hline & Hospitality & 0.712 & 0.295 & 5.819 & 1 & 0.016 & 2.037 \\
\hline & Relaxing & 0.842 & 0.295 & 8.171 & 1 & 0.004 & 2.322 \\
\hline & Atmosphere & & & & & & \\
\hline & Constant & -16.126 & 4.011 & 16.162 & 1 & 0.000 & 0.000 \\
\hline \multirow[t]{6}{*}{ Cultural Tourism } & Accommodation & 0.573 & 0.256 & 5.016 & 1 & 0.025 & 1.774 \\
\hline & $\begin{array}{l}\text { Conservation of } \\
\text { resources }\end{array}$ & 0.551 & 0.198 & 7.757 & 1 & 0.005 & 1.734 \\
\hline & Hospitality & 1.225 & 0.265 & 21.335 & 1 & 0.000 & 3.405 \\
\hline & Natural Environment & 0.587 & 0.218 & 7.233 & 1 & 0.007 & 1.798 \\
\hline & Night Life & 0.509 & 0.184 & 7.647 & 1 & 0.006 & 1.664 \\
\hline & Constant & -14.725 & 2.403 & 37.564 & 1 & 0.000 & 0.000 \\
\hline
\end{tabular}

considered relevant; (3) concerning cultural destinations, hospitality towards the tourist is amply pondered, although the quality of the destination also depends on the presence of natural spaces, on the appropriate conservation of the resources and on the alternative existence of night life.

The improvement of quality is one of the main challenges of the tourist industry in order to be able to compete in the current markets. For this reason, in actual competitive environment, the results of this research have a clear implication on how to manage companies so that they operate to improve the different tourist destinations quality from the tourist's view. Specifically, the key attribute of each type of tourist product could be extracted, so that destination managers could concentrate their marketing efforts on improving competitiveness through quality. In this sense, tourists perceive that a sun-sea-sand destination that is not overcrowded has better quality; rural tourism destinations must improve some aspects such as the related to cleanliness if they want their visitors to link them with better quality; cultural tourism destinations could improve perceived quality reflecting their concerns on making local population and entrepreneurs more welcoming with tourists. None of these aspects had been found in literature, so this is the main contribution of this research.

\section{References}

Alegre, J. \& Cladera M. (2006). Repeat visitation in mature sun and sand holiday destinations. Journal of Travel Research, 44(3), 288-297.

Baker, D. A. \& Crompton, J. L. (2000). Quality, satisfaction and behavioral intentions. Annals of Tourism Research, 27(3), 785-804.

Baloglu, S., Pekcan, A., Chen, S. L. \& Santos, J. (2003). The relationship between destination performance, overall satisfaction, and behavioral intention for distinct segments. Journal of Quality Assurance in Hospitality \& Tourism, 4(3/4), 149-165.

Bigné, J. E., Font, X. \& Andreu, L. (2000) Marketing de destinos turísticos: análisis y estrategias de desarrollo. Madrid: Esic.

Carman, J. M. (1990). Consumer perceptions of service quality: an assessment of the SERVQUAL dimensions. Journal of Retailing, 66(1), 33-55.

Dwyer, L., Mellor, R., Livaic, Z., Edwards, D. \& Kim, C. (2004). Attributes of destination 
competitiveness: a factor analysis. Tourism Analysis, 9(1/2), 91-101.

Fallon, P. \& Schofield, P. (2006). The dynamics of destination attribute importance. Journal of Business Research, 59(6), 709-713.

Hui, T. K., Wan, D. \& Ho, A. (2007). Tourists' satisfaction, recommendation and revisiting Singapore. Tourism Management, 28(4), 965-975.

Illum, S. \& Schaefer, A. (1995) Destination attributes: perspectives of motor coach tour operators and destination marketers. Journal of Travel \& Tourism Marketing, 4(4), 1-14.

Kandampully, J (2000). The impact of demand fluctuation on the quality of service: a tourism industry example. Managing Service Quality, 10(1), 10-19.

Kozak, M. (2001). Comparative assessment of tourist satisfaction with destinations across two nationalities. Tourism Management, 22(4), 391-401.

Kozak, M., Bigné, E. \& Andreu, L. (2004). Satisfaction and destination loyalty: a comparison between non-repeat and repeat tourists. Journal of Quality Assurance in Hospitality \& Tourism, 5(1), 43-59.

Kozak, M. \& Rimmington, M. (2000). Tourist satisfaction with Mallorca, Spain, as an off-season holiday destination. Journal of Travel Research, 38(3), 260-269.

Kvist, A. J. \& Klefsjo, B. (2006). Which service quality dimensions are important in inbound tourism? A case study in a peripheral location. Managing Service Quality, 16(5), 520-537.

McKercher, B. \& Wong, D. (2004). Understanding tourism behavior: examining the combined effects of prior visitation history and destination status. Journal of Travel Research, 43(2), 171-179.

Murphy, P., Pritchard, M. P. \& Smith, B. (2000). The destination product and its impact on traveller perceptions. Tourism Management, 21(1), 43-52.

Narayan, B., Rajendran, C., Sai, L. P. \& Gopalan, R. (2009). Dimensions of service quality in tourism - an Indian perspective. Total Quality Management, 20(1), 61-89.

Pizam, A. \& Milman, A. (1993). Predicting satisfaction among first time visitors to a destination by using the expectancy disconfirmation theory. International Journal of Hospitality Management, 12(2), 197-209.

Pizam, A., Neumann, Y. \& Reichel, A. (1978). Dimensions of tourist satisfaction with a destination area. Annals of Tourism Research, 5(3) 314-322.

Tam, J. L. (2000). The effects of service quality, perceived value and customer satisfaction on behavioral intentions. Journal of Hospitality \& Leisure Marketing, 6(4), 31-43.

Teas, R. K. (1993). Expectations, performance evaluation and consumer's perceptions of quality. Journal of Marketing, 57(4), 18-34.

Weaver, P. A., Weber, K. \& McCleary K. W (2007). Destination evaluation: the role of previous travel experience and trip characteristics. Journal of Travel Research, 45(3), 333-344.

Weiermair, K. \& Fuchs, M. (1999). Measuring tourist judgment on service quality. Annals of Tourism Research, 26(4), 1004-1021. 